\title{
Peptidyl-Prolyl Cis-Trans Isomerase B
}

National Cancer Institute

\section{Source}

National Cancer Institute. Peptidyl-Prolyl Cis-Trans Isomerase B. NCI Thesaurus. Code C115181.

Peptidyl-prolyl cis-trans isomerase B $(216 \mathrm{aa}, \sim 24 \mathrm{kDa})$ is encoded by the human PPIB gene. This protein plays a role in the mediation of protein folding. 